\title{
Plućni embolizam u pneumoniji
}

\section{Pulmonary Embolism in Pneumonia}

\author{
Bea Hohšteter ${ }^{1}$, Lidija Ljubičić, Gordana Pavliša ${ }^{1,2}$ \\ ${ }^{1}$ Medicinski fakultet Sveučilišta u Zagrebu, Hrvatska \\ ${ }^{2}$ Klinika za plućne bolesti Jordanovac, Klinički bolnički centar Zagreb, Hrvatska
}

Ključne riječi:
plućni embolizam
pneumonija
D-dimeri
COVID-19
antikoagulansi
Keywords:
pulmonary embolism
pneumonia
D-dimers
COVID-19
anticoagulants

Primljeno: $13-10-2020$

Received: $13-10-2020$

Prihvaćeno: 12-11-2020

Accepted: $12-11-2020$

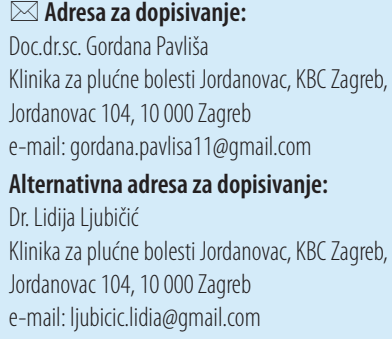

\begin{abstract}
Sažetak
Plućni embolizam (PE) i pneumonija dijele zajedničke rizične faktore, uzajamno se potenciraju i slično radiološki manifestiraju. Klinička slika pneumonije može u potpunosti maskirati prateću PE što uz porast D-dimera uslijed upalnog zbivanja znatno otežava probir pacijenata koje je potrebno podvrgnuti slikovnim metodama dijagnostike. Još uvijek nije pronađeno neko karakteristično obilježje (niti granična vrijednost D-dimera) koje bi direktno sugeriralo prisutnost PE u osobe s pneumonijom. Prateća PE najčešće se javlja u starijih i bolesnika s komorbiditetima, a bol u prsima, dispneja i sinkopa češće su nego kod pneumonije bez PE. Pojavnost PE u bolesnika s pneumonijom uzrokovanom novim koronavirusom (COVID-19) značajno je veća nego u pneumonija uzrokovanih drugim uzročnicima i povezuje se s rizičnim faktorima poput muškog spola, višim razinama C-reaktivnog proteina te odgodom hospitalizacije. Primjena profilaktičke doze antikoagulantne terapije može reducirati učestalost PE u bolesnika s COVID-19 pneumonijom.
\end{abstract}

\begin{abstract}
Summary
Pneumonia and pulmonary embolism (PE) share common risk factors, radiological findings and one disease may induce the development of another. The clinical characteristics of pneumonia can completely mask the concomitant PE, which, along with the increase in D-dimer due to inflammatory events, significantly complicates the screening of patients who need imaging diagnostic methods. A specific feature (including the exact D-dimer cut-off value), which would clearly indicate concomitant PE in pneumonia has not yet been established. However, older age, comorbidities, chest pain, dyspnea and syncope are more common in pneumonia with coexisting PE than in pneumonia alone. In new coronavirus associated pneumonia (COVID-19), PE is far more frequent than in pneumonia caused by other microorganisms. PE in COVID-19 pneumonia is associated with risk factors such as male sex, higher levels of C-reactive protein and delayed hospitalization. Anticoagulant-prophylaxis reduces the incidence of PE in COVID-19 pneumonia.
\end{abstract}

\section{Uvod}

Plućni embolizam (PE) i pneumonija obilježeni su brojnim sličnostima u rizičnim faktorima, kliničkim, laboratorijskim i radiološkim obilježjima, zbog čega uspješna distinkcija među ovim patološkim zbivanjima može predstavljati dijagnostički izazov. Poseban dodatni problem leži u mogućoj istovremenoj prisutnosti PE i pneumonije, osobito u specifičnim populacijama bolesnika ${ }^{[1-3]}$.

Sama pneumonija potencira razvoj venskog tromboembolizma (engl. venous thromboembolism, VTE) i zbog povećane koagulabilnosti u sklopu infektivnog zbivanja, ali i zbog mirovanja bolesnika i nastanka ven- ske staze tijekom akutne bolesti ${ }^{[4]}$. S druge strane, zbog opstrukcije, u PE nastaje hipovaskulariziran, moguće i nekrotični plućni parenhim koji ima izvrsnu predispoziciju postati ishodištem infektivnog zbivanja - pneumonije (tzv. infarkt pneumonija ${ }^{[1]}$ ), čime se zatvara patofiziološki circulus vitiosus i otvara pitanje „Što je bilo prvo- PE ili pneumonija?". O međusobnoj povezanosti ovih etiološki posve različitih stanja, svjedoči i preklapanje u čimbenicima koji mogu precipitirati njihov nastanak - nedavna imobilizacija, kronična kardiovaskularna ili plućna bolest te aktivni malignitet, dobro su poznati rizični faktori za nastanak i PE i pneumonije $\mathrm{e}^{[4]}$. 
U istraživanju koje je obuhvaćalo 2387 bolesnika zaprimljenih na liječenje zbog izvanbolničke pneumonije, prisutnost PE uz pneumoniju potvrđena je kod 80 (3\%) osoba ${ }^{[5]}$.

U retrospektivnoj kohortnoj studiji provedenoj na uzorku 18928 bolesnika s pneumokoknom pneumonijom i 75712 kontrola, analiziran je rizik za razvoj VTE u osoba oboljelih od pneumokokne pneumonije, kao najčešće izvanbolničke pneumonije u odraslih. Incidencija DVT-a je u oboljelih od pneumonije iznosila 1,24 na 1000 osoba-godina, a omjer incidencija DVT-a među slučajevima i kontrolama iznosio je 1,95 (95\% confidence interval, CI: 1,85-2,06). Incidencija same PE bila je čak 2,23 puta veća među oboljelima od pneumonije, nego među kontrolama. Svi ispitivani komorbiditeti koji bi mogli djelovati kao rizični faktori i precipitirati DVT, bili su učestaliji u osoba s pneumonijom, nego u kontrola $(\mathrm{p}<0,0001)$. Međutim, i nakon provođenja regresijske analize, pneumokokna pneumonija potvrđena je kao neovisni rizični čimbenik za razvoj DVT-a. Najviša incidencija tromboembolijskih incidenata zabilježena je u prvih mjesec dana po infekciji pneumokokom, no povećan rizik bio je prisutan čak još godinu dana ${ }^{[6]}$.

Rezultati studije u kojoj je na uzorku od 794 bolesnika s potvrđenom $\mathrm{PE}$ istraživana mogućnost prateće pneumonije, pokazali su kako je pneumonija uz PE bila prisutna kod 36 (5\%) bolesnika, a u 6 je osoba (1\%) bila jedini rizični čimbenik za razvoj $\mathrm{VTE}^{[4]}$.

$\mathrm{U}$ specifičnim populacijama, primjerice $\mathrm{u}$ osoba hospitaliziranih zbog akutne egzacerbacije kronične opstruktivne plućne bolesti (KOPB), prevalencija PE je prema rezultatima jedne meta-analize iznosila čak $19,9 \%$, iako u ovoj studiji bolesnici nisu jasno podijeljeni na one s pneumoničnim i ne-pneumoničnim KOBP egzacerbacijama ${ }^{[7]}$.

Istovremena pojavnost $\mathrm{PE}$ i pneumonije načelno nije pretjerano česta, no ipak je valja imati na umu radi pravovremene primjene terapije. Stope smrtnosti u neliječenom PE penju se do čak $25 \%{ }^{[8]}$, a definiranje parametara koji bi jasnije sugerirali kojim je osobama s pneumonijom potrebna daljnja obrada zbog moguće konkomitantne PE i dalje je u fokusu mnogih istraživanja.

\section{Dijagnostičke dileme u pneumoniji praćenoj pluć- nim embolizmom}

Prema aktualnim nacionalnim smjernicama, na izvanbolničku pneumoniju upućuju novonastali kašalj praćen febrilitetom, dispnejom / tahipnejom, bolom u prsima ili auskultatorno čujnim krepitacijama. Međutim, bolesnici se mogu prezentirati i bez karakterističnih simptoma, zbog čega je za potvrdu pneumonije potrebno učiniti i sumacijsku rentgensku snimku (RTG) torakalnih organa i vizualizirati infiltrat ${ }^{[9]}$. Radiološka potvrda novonastalog infiltrata (uz kliničke znakove infekta i porast upalnih parametara) ključna je i u dijagnostici bolničke pneumonije i pneumonije povezane s mehaničkom ventilacijom ${ }^{[10]}$.

Postavljanje ili isključivanje kliničke sumnje na PE još je problematičnije: kao najčešći simptomi navode se dispneja, bol u prsima, hemoptiza, presinkopa i sinkopa, no PE se može javiti i kao potpuno asimptomatsko zbivanje, a u slučaju masivne PE prezentira se slikom kardiogenog šoka ${ }^{[1,12]}$. Zbog široke palete simptoma i znakova manifestacije PE, koriste se preddijagnostički testovi za procjenu vjerojatnosti njenog postojanja (Wellsova ocjenska ljestvica, Geneva kriteriji) te se u kombinaciji s povišenim vrijednostima D-dimera postavlja indikacija za kompjuteriziranu tomografsku plućnu angiografiju (CTPA), pretragu kojom se potvrđuje ili isključuje PE. Razlog takvom „stepeničastom” pristupu do CTPA, leži u rizicima i kontraindikacijama vezanim uz ovu pretragu (izlaganje radijaciji, trudnoća, hipertireoza, alergija na kontrastno sredstvo ili njegova otežana eliminacije u bubrežnih bolesnika) te je važno dobro selektirati osobe u kojih je CTPA zaista i potrebna ${ }^{[13]}$.

Prisutnost pneumonije otežava postavljanje sumnje na PE i zbog navedenih preklapajućih elemenata u kliničkoj slici, zbog sličnosti RTG nalaza (konsolidacija- infektivni infiltrat ili plućni infarkt? $\left.{ }^{[4]}\right)$, zbog zajedničkih rizičnih faktora, ali i iz razloga što pneumonija (kao infektivno zbivanje) dovodi do porasta D-dimera te tako potpuno kompromitira parametre temeljem kojih postavljamo indikaciju za CTPA.

D-dimeri su produkt metabolizma fibrina i time indikatori trenutnog ili nedavnog formiranja ugruška. Kvantitativno, vrijednosti D-dimera mogu biti izražene kao masena koncentracija fibrinogen-ekvivalentnih jedinica (engl. fibrinogen equivalent units, FEU) ili jediničnih D-dimera (engl. D-dimer unit, DDU). FEU se odnosi na masu inicijalno prisutnog fibrinogena čijim raspadom nastaju jedinični fragmenti $\mathrm{D}$-dimera, mase otprilike upola manje nego ishodišni fibrinogen. $1 \mu \mathrm{g} /$ $\mathrm{mL}$ FEU stoga je ekvivalentan.0,5 $\mu \mathrm{g} / \mathrm{mL}$ DDU ${ }^{[14]}$.

Negativna prediktivna vrijednost D-dimera je iznimno visoka: smatra se kako praktički ne postoji mogućnost za PE ukoliko je vrijednost $\mathrm{D}$-dimera $<500$ $\mu \mathrm{g} / \mathrm{L}$ FEU. Već je više od dva desetljeća poznato kako se u starije populacije često mogu pronaći povišene koncentracije D-dimera, čak i u odsustvu detektabilnog VTE ${ }^{[15,16]}$. Na uzorku od 1029 bolesnika obrađenih zbog sumnje na PE, ispitana je senzitivnost i specifičnost povišenih ( $>500 \mu \mathrm{g} / \mathrm{L} \mathrm{FEU})$ vrijednosti D-dimera kao pretrage probira u PE. U mlađim dobnim skupinama (<40 god.), specifičnost je iznosila $67 \%$, dok 
je u starijih od 80 godina, specifičnost iznosila svega $10 \%{ }^{[15]}$. Nizovi studija sa sličnim rezultatima pokazali su kako je u starije populacije vrijednost D-dimera viša nego u mlađih ljudi. Stoga je prema trenutnim smjernicama, gornja granica referentnog raspona $\mathrm{u}$ osoba starijih od 50 godina, definirana kao dob izražena u godinama x $10 \mu \mathrm{g} / \mathrm{L} \mathrm{FEU}^{[13]}$. Primjenom takvih, dobi prilagođenih vrijednosti D-dimera, mogućnost isključenja PE u starijih osoba povećava se za čak 5 puta, a bez korištenja dodatne nepotrebne dijagnostike ${ }^{[17]}$.

Razina D-dimera u bolesnika s pneumonijom statistički je značajno povezana rizikom za slabije preživljenje ili teži klinički tijek ${ }^{[18]}$. U jednoj od recentnijih studija posvećenih upravo toj problematici, srednja vrijednost D-dimera iznosila je 2080 (1050-3410) $\mu \mathrm{g} / \mathrm{L}$ DDU, što jasno ilustrira koliko pneumonija modulira vrijednost ovog parametra i otežava probir pacijenata s mogućim $\mathrm{PE}^{[19]}$. Osim u pneumoniji, vrijednosti D-dimera mogu biti povišene i u brojnim drugim stanjima (malignitet, recentna trauma, sepsa ili bilo koje infektivno zbivanje) od kojih su mnoga upravo zajednički rizični faktori i PE i pneumonije ${ }^{[13]}$.

\section{„Prototip bolesnika” u pneumoniji praćenoj pluć- nim embolizmom}

Šangajska prospektivna kohortna studija analizirala je rizične faktore te kliničke i parakliničke parametre u osoba s pneumonijom i pratećim PE. U studiju su uključeni bolesnici hospitalizirani zbog liječenja izvanbolničke pneumonije, a D-dimeri rutinski su mjereni svima pri prijemu. Čak trećina osoba imala je povišene vrijednosti $\mathrm{D}$-dimera $(>0,55 \mathrm{mg} / \mathrm{L} \mathrm{FEU})$, no CTPA je učinjena samo ukoliko je postavljena sumnja na prisutnost PE kod pojedinog bolesnika. Osobe s potvrđenom PE imale su statistički značajno više vrijednosti D-dimera (medijan 2,83 mg/L), nego osobe bez PE (medijan 1,41 g/L). Starosni medijan u bolesnika s potvrđenim PE iznosio je 72 godine, a u osoba bez PE 69 godina. Značajnost dobi kao neovisnog rizičnog faktora za nastanak PE u pneumoniji potvrđen je i multivarijantnom analizom. Barem jedan od istraživanih komorbiditeta bio je prisutan u $87 \%$ bolesnika s PE. Ako je bila riječ o osobi, kod koje su postojala 3 ili više komorbiditeta, omjer vjerojatnosti (engl. odds ratio, OR) za PE iznosio je čak 3,544 (95\% CI 1,639$7,661 ; \mathrm{p}=0,001)$. Nakon provođenja multivarijantne analize, KOPB se pokazao najjačim neovisnim rizičnim čimbenikom za nastanak PE (OR = 7,232 95\%; CI 7,232-863,951; $\mathrm{p}=0,002$ ), a pozitivna korelacija pronađena je i za koronarnu bolest srca i varikozitete nogu. Od simptoma i znakova kao oni koji najsnažnije sugeriraju PE izdvojili su se dispneja $(\mathrm{OR}=1,57$; CI $1,57-145,88 ; \mathrm{p}=0,019)$, bol u prsima $(\mathrm{OR}=2,723 ; 95 \%$
CI 2,723-194,638; $\mathrm{p}=0,004)$ i hemoptiza $(\mathrm{OR}=2,309$; 95\% CI 2,309-137,905; p = 0,006). Za sinkopu, otok nogu i stezanje u grudnom košu, provođenjem univarijantne analize, nije pronađena statistički značajna korelacija s vjerojatnošću za PE ( $p>0,05)$.

Od laboratorijskih parametara, pronađena je povezanost prateće $\mathrm{PE} s$ povišenjem vrijednosti C-reaktivnog proteina (CRP) i troponina I, dok se prisutnost acidoze, povećanih vrijednosti moždanog natriuretičkog peptida, hiperkapnije ili poremećaj vrijednosti fibrinogena nisu pokazali statistički značajnima ( $\mathrm{p}>$ $0,05)^{[5]}$.

U istraživanju suprotnog polazišta ${ }^{[4]}$, u kojem su analizirane kliničke, laboratorijske i radiološke razlike među 3 kategorije bolesnika s potvrđenim PE, jednu od kategorija činile su upravo osobe s PE i istovremenom pneumonijom. Rezultati su pokazali kako su bolesnici u kojih se simultano javljaju pneumonija i plućni embolizam prosječno više životne dobi (medijan 74 godine), češće muškarci (59,3\%) i statistički značajno manjeg indeksa tjelesne mase (engl. body mass index, BMI medijan $=21 \mathrm{~kg} / \mathrm{m}^{2}$ ) nego osobe iz ostale dvije skupine (osobe s neprovociranom PE te osobe s PE i plućnim infarktom). Gotovo $70 \%$ osoba s pneumonijom bilo je nedavno imobilizirano, 22,2\% njih operirano ili doživjelo traumu, a u $13,9 \%$ postojao je aktivni malignitet. Učestalost moždanog udara iznosila je $22,2 \%$, a od drugih su komorbiditeta najčešći bili diabetes mellitus (19,4\%) i spektar kroničnih plućnih bolesti (16,7\%). U bolesnika s istovremenom pneumonijom i PE, centralna je embolija (16,7\%), kao i znakovi preopterećenja desnog srca $(27,8 \%)$, bila statistički značajno manje učestala nego u preostale dvije skupine, no upravo je grupa s pneumonijom imala najveću $(16,7 \%)$ intrahospitalnu smrtnost ${ }^{[4]}$.

Paparoupa i suradnici proveli su retrospektivnu studiju slučajeva i kontrola (engl. case - control study), s ciljem konstrukcije sheme za probir osoba s pneumonijom u kojih postoji izglednija mogućnost postojanja prateće PE. U studiju su uključeni bolesnici s pneumonijom u kojih je zbog sumnje na PE učinjena CTPA. Bolesnici s PE služili su kao slučajevi, a oni u kojih PE nije dokazana CT pulmonalnom angiografijom - kao kontrole. Sparivanje je uspješno provedeno za 90 bolesnika (ukupno 45 parova slučaj - kontrola). Ideja njihove studije bila je pronaći model za probir temeljen na razlikama koje se očituju u odabranim kliničkim, laboratorijskim i radiološkim parametrima između slučajeva i kontrola. Osobe uključene u studiju nisu imale $\mathrm{PE} \mathrm{u}$ anamnezi, niti primale kroničnu terapiju antagonistima vitamina $\mathrm{K}$.

Većina je bolesnika (60\%) bila muškog spola, a prosječna starost ispitanika bila je 66 godina. Glavni analizirani simptomi bili su prisutnost vrućice i boli 
u prsima. Vrućica se u obje skupine javila sa sličnom učestalošću, a bol u prsima bio je statistički značajno $(\mathrm{p}=0,032)$ učestaliji među slučajevima $(53,33 \%)$ u odnosu na kontrole (35,56\%). Dispneja, sinkopa i „odsustvo drugih simptoma osim glavnih" također su bili češći u skupini slučajeva, dok su kašalj i hemoptiza bili učestaliji među kontrolama, no bez statistički značajne razlike $(\mathrm{p}=0,588)$. Ukupni broj leukocita ni vrijednost CRP-a nisu se značajno razlikovali među dvije grupe, za razliku od vrijednosti D-dimera koje su bile statistički značajno više među slučajevima. Ipak, optimalna granična vrijednost D-dimera, koja bi omogućila zadovoljavajuću specifičnost selekcije slučajeva s PE, nije pronađena. Tražena shema za probir bolesnika na temelju kliničkih i parakliničkih obilježja također nije pronađena. Od svih testiranih modela, jedino su modeli kombinacije boli u prsima s povišenim vrijednostima $\mathrm{D}$-dimerima i povišenih $\mathrm{D}$-dimera uz prisutnu konsolidaciju vidljivu na RTG-u pokazivali nešto veću specifičnost od povišenih D-dimera samostalno. Njihov diskriminatorni potencijal ipak nije bio toliko dramatično bolji da bi se mogli smatrati zadovoljavajućim alatom za široku kliničku primjenu ${ }^{[1]}$.

\section{Plućni embolizam u pneumoniji uzrokovanoj novim koronavirusom}

Već u prvim mjesecima od izbijanja pandemije uzrokovane novim koronavirusom (SARS-CoV-2), primijećena je povećana učestalost novonastalih tromboembolijskih inicidenata među oboljelima.

Povezanost specifičnog uzročnika s povećanom frekvencijom nastanka VTE nije nova pojava: prije desetak godina, $u$ vrijeme intenzivnog širenja influence uzrokovane H1N1 virusom, kanadsko retrospektivno istraživanje analiziralo je učestalost trombotskih incidenata među zahvaćenom populacijom. Od 119 bolesnika zaprimljenih na liječenje zbog $\mathrm{H} 1 \mathrm{~N} 1$ influence, $\mathrm{u}$ njih 7 (5,9\%) se razvila tromboza (4 arterijske i 3 venske). Smrtnost među bolesnicima s trombozom bila je veća $(31 \%)$ nego u osoba bez trombotskog inicidenta $(8 \%)$, no bez statistički značajne razlike $(\mathrm{p} .=0,07)^{[20]}$.

Prema izvješću francuskog centra za tercijarnu skrb, od 107 pacijenata zaprimljenih u jedinicu intenzivnog liječenja (JIL) zbog COVID-19, u njih čak 22 (20,6\%), razvio se $\mathrm{PE}^{[21]}$. Ta je brojka neobično visoka, s obzirom da se među bolesnicima u JIL-u, DVT očekuje u $5 \%$ do $10 \%$ slučajeva. Centar u kojem je provedena analiza zbrinjava bolesnike iz "metaboličke” regije, poznate po velikom broju osoba s prekomjernom tjelesnom težinom te je rizik za razvoj DVT-a u toj populaciji zasigurno povećan. Ipak, u usporedbi s „kontrolnom skupinom" (sastavljenom od jednako ugroženih bolesnika, iz iste populacije, zaprimljenih na isti JIL u istom periodu godinu dana ranije), frekvencija pojavnosti PE među COVID-19 pacijentima bila je dvostruko veća ${ }^{[22]}$.

Trombogeni potencijal COVID-19 posljedica je višestrukih poremećaja sastavnica Virchowljevog trijasa pa nastanak VTE i unatoč antitrombotskoj profilaksi i nije toliko iznenađujući, osobito među bolesnicima u JIL-u ${ }^{[23]}$

SARS-Co-V-2 infekcija pokreće ekscesivnu aktivaciju komplementa ${ }^{[24]}$ i citokinsku oluju koja dovodi do porasta koncentracije plazmatskog fibrinogena, faktora koagulacije i aktivacije trombocita ${ }^{[25,26]}$. Prema nedavno objavljenoj meta-analizi, visoka koncentracija proinflamatornih citokina poput interleukina 2, $6 \mathrm{i}$ 8 te TNF-a (engl. tumor necrosis factor), statistički je značajno povezana s lošijom prognozom ${ }^{[27]}$. S obzirom da je ulazno mjesto za SARS-CoV-2 upravo ACE2 (eng. angiotensin-converting enzyme 2) receptor koji izražavaju i stanice endotela, COVID-19 dovodi i do destrukcije endotelijalnog glikokalisa, otpuštanja tkivnog plazminogenskog aktivatora (tPA) i inhibitora aktivacije plazminogena $(\mathrm{PAI})^{[25]}$.

Koagulopatija povezana s COVID-19 (eng. COVID-associated coagulopathy, CAC) razvija se dakle i zbog prokoagulantnog potencijala upale i zbog narušavanja antitrombotskih svojstava endotela. Osim što je usko vezana uz VTE, CAC precipitira razvitak obilja mikrotromba u plućnoj cirkulaciji te je, uz destrukciju samog plućnog parenhima, temeljni patofiziološki proces nastanka akutne ozljede pluća (engl. acute lung injury, ALI) povezane s COVID-om ${ }^{[25,26]}$.

U retrospektivnoj studiji specifično orijentiranoj na PE u COVID-19 pneumoniji ${ }^{[28]}$, također je potvrđena vrlo visoka incidencija PE: u čak $24 \%$ svih osoba s pneumonijom, CTPA-om je potvrđen PE. 70\% bolesnika podvrgnutih CTPA bili su muškarci. U otprilike polovice, sumnja na prateću PE postavljena je odmah pri prijemu, a ostatak su činile već hospitalizirane osobe koje su se klinički pogoršavale. U grupi s PE, vrijednosti D-dimera bile su značajno veće, nego u grupi bez PE $(9871 \mu \mathrm{g} / \mathrm{L}$ u odnosu na $1285 \mu \mathrm{g} / \mathrm{L} ; \mathrm{p}<0,001)$. U grupi bolesnika s PE, u $38 \%$ slučajeva bio je potreban premještaj u JIL i u 31\% mehanička ventilacija, za razliku od osoba bez PE kojih je u JIL premješteno 12\%, a intubirano $8 \%(\mathrm{p}=0,001)^{[28]}$.

Prema rezultatima jedne od prvih COVID-19 retrospektivnih kohortnih studija, temeljenoj na uzorku od 191 bolesnika iz Wuhana, među onima s vrijednostima D-dimera $>1,0 \mathrm{mg} / \mathrm{L}$ FEU, OR za smrtnost iznosio je čak $18^{[29]}$. I kasnije studije provedene na većim uzorcima, potvrdile su statistički značajnu povezanost vrijednosti D-dimera u prognozi COVID-19 ${ }^{[30]}$.

PE u COVID-19 pneumoniji obilježen je i nekim radiološkim specifičnostima, koje ne iznenađuju s ob- 
zirom na patofiziologiju CAC-a i ALI: uglavnom se viđaju sitniji tromboembolusi koji zahvaćaju upravo prostor u kojem postoji pneumonijski infiltrat, odnosno, ishodište najveće upalne aktivnosti (najčešće subsegmentalne arterije u desnom plućnom krilu). Sukladno tome, centralna opstrukcija i posljedično opterećenja desnog srca, viđaju se nešto rjeđe ${ }^{[31,32]}$.

Multicentrična retrospektivna studija provedena na uzorku od 2878 bolesnika hospitaliziranih zbog COVID-19, sugerira kako su za nastanak PE tijekom infekcije SARS-CoV-2 virusom odgovorni i specifični rizični čimbenici, koji se ne ubrajaju u tradicionalne rizične faktore za VTE. Prema rezultatima multivarijantne regresijske analize, rizik je povećan za osobe muškog spola $(\mathrm{OR}=1,09 ; 95 \%$ CI 1,003-1,069; p = 0,04), osobe u kojih je proteklo više vremena od nastupa simptoma do hospitalizacije (OR $=1,02$; 95\%CI 1,0061,038; $\mathrm{p}=0,001)$ te bolesnike $s$ visokim vrijednostima CRP-a (OR 1,03; 95\% CI 1,01-1,04; p = 0,001) ${ }^{[33]}$. Veća učestalost pneumonije s pratećim PE među muškarcima uočena je i inače, no nije pokazivala statističku značajnost. Produljeno vrijeme od pojave simptoma do hospitalizacije, rizični je čimbenik s obzirom da je obično riječ o osobama koje ne prime antikoagulantnu terapiju ili ju ne prime u dovoljnoj dozi. Kao protektivni faktori djeluju, dakle, profilaktičko uvođenje antikoagulantne terapije već pri zaprimanju SARS-CoV-2 pozitivnog bolesnika ( $\mathrm{OR}=0,83$; 95\% CI 0,79-0,92; p $<0,001)$ te terapijska doza antikoagulansa prije hospitalizacije $(\mathrm{OR}=0,87 ; 95 \%$ CI 0,82-0,92; $\mathrm{p}<0,001)$. Iz tog se razloga sugerira uvođenje profilaktičke antikoagulantne terapije osobama hospitaliziranima zbog COVIDa-19, a u izabranim slučajevima i osobama na kućnom liječenju, s blažim oblikom bolesti ${ }^{[33,34]}$.

\section{Zaključak}

Postavljanje sumnje na PE u bolesnika s pneumonijom i selekcija bolesnika za CTPA, kompleksna je i neriješena problematika. Konkretna shema za probir bolesnika ne postoji i upitna je vjerojatnost konstrukcije iste s obzirom da ključni faktori za procjenu (klinička obilježja i D-dimeri) mogu biti modulirani međusobno, ali i velikim brojem drugih, nepovezanih zbivanja. U bolesnika kod kojih postoji klinička sumnja, primjerice izrazito povišene vrijednosti D-dimera ili izostanak rezolucije stanja ${ }^{[5]}$ i nakon uvođenja adekvatne antimikrobne terapije, svakako se preporuča učiniti CTPA.

$\mathrm{U}$ svim spomenutim studijama, vrijednost D-dimera bila je statistički značajno različita u osoba s pratećim PE, u odnosu na osobe bez PE, no kvantitativna uniformnost koja bi omogućila postavljanje konkretnih brojčanih granica nije uočena. Uvidom u recentne publikacije, čimbenici koji se ponavljano spominju i mogli bi sugerirati prisustvo PE u pneumoniji su: visoka životna dob bolesnika (medijan u svih $>65$ godina), prisutnost KOPB-a i kroničnih kardiovaskularnih bolesti (osobito ako je prisutno više komorbiditeta), prisutnost „velikih” rizičnih faktora za VTE (nedavna trauma ili operacija, imobilizacija, aktivni malignitet).

Od elemenata kliničke prezentacije, bol u prsima se ističe kao parametar koji je u svim radovima pokazivao statistički značajno veću prisutnost u osoba s PE. Dispneja i sinkopa također su bile češće među osobama s PE, no bez stalne statističke značajnosti. Hemoptiza je pokazivala različitu učestalost, ovisno o istraživanju (od neovisnog rizičnog čimbenika povezivog s $\mathrm{PE}$, do faktora koji je učestaliji u grupi bez PE). Vrijednosti upalnih parametara, kao što su brzina sedimentacije, ukupni broj leukocita, CRP, također su imale šaroliku distribuciju i ne mogu se interpretirati jednoznačno.

U COVID-19 pneumoniji, incidencija PE neobično je visoka, zbog čega se preporuča uvođenje antikoagulantne terapije svim hospitaliziranim osobama, osim ako ne postoje kontraindikacije za istu. Uz VTE nastao uslijed COVID-19, vežu se i neki dodatni rizični faktori, kao što su muški spol, visoke vrijednosti CRP-a i produljeno vrijeme od pojave simptoma do hospitalizacije.

\section{LITERATURA}

${ }^{[1]}$ Paparoupa M, Spineli L, Framke T, Ho H, Schuppert F, Gillissen A. Pulmonary Embolism in Pneumonia: Still a Diagnostic Challenge? Results of a Case-Control Study in 100 Patients. Dis Markers 2016;2016:8682506.

${ }^{[2]}$ Söderberg M, Hedström U, Sjunnesson M, Lärfars G, Jorup-Rönström C. Initial symptoms in pulmonary embolism differ from those in pneumonia: A retrospective study during seven years. Eur J Emerg Med 2006;13(4): 225-9.

${ }^{[3]}$ Trethewey SP, Hurst JR, Turner AM. Pneumonia in exacerbations of COPD: what is the clinical significance? ERJ Open Res 2020;6(1):00282-02019.

${ }^{[4]}$ Cha SI, Choi KJ, Shin KM, et al. Clinical characteristics of pulmonary embolism with concomitant pneumonia. Blood Coagul Fibrinolysis 2016;27(3):281-286.

${ }^{[5]}$ Zhang Y, Zhou Q, Zou Y, et al. Risk factors for pulmonary embolism in patients preliminarily diagnosed with community-acquired pneumonia: a prospective cohort study. J Thromb Thrombolysis 2016;41(4):619-27.

${ }^{[6]}$ Chen YG, Lin TY, Huang WY, Lin CL, Dai MS, Kao CH. Association between pneumococcal pneumonia and venous thromboembolism in hospitalized patients: A nationwide population-based study. Respirology 2015;20(5):799-804.

${ }^{[7]}$ Rizkallah J, Man SFP, Sin DD. Prevalence of pulmonary embolism in acute exacerbations of COPD. Chest 2009;135(3):786-93.

${ }^{[8]}$ Pulmonary Embolism Severity Index (PESI) - MDCalc. Available at: https://www.mdcalc.com/pulmonary-embolism-severityindex-pesi. Accessed on September 15, 2020.

${ }^{[9]}$ Kuzman I, Kutleša M, Čivljak R, et al. Guidelines for the management of community-acquired pneumonia in adults. Liječnič Vjesn 2017;139(7-8):177-191. 
${ }^{[10]}$ Karin A, Peršec J, Bakran K, Pražetina M, Šribar A. Etiology, incidence and mortality in patients with ventilator-associated pneumonia in adult general surgery and cardiac surgery intensive care units in University Hospital Dubrava. Infektol Glasn 2019;39:124-8.

${ }^{[11]}$ Wilkinson IB, Raine T, Wiles K, Goodhart A, Hall C, O’Neill H. Emergencies. Pulmonary embolism (PE). In: Oxford Handbook of Clinical Medicine. 10th Ed. New York, NY: Oxford University Press, 2017: 818-9.

${ }^{[12]}$ Rvu JH, Olson EJ, Pellikka PA. Clinical Recognition of Pulmonary Embolism: Problem of Unrecognized and Asymptomatic Cases. Mayo Clinic Proceedings 1998; 73: 873-9.

${ }^{[13]}$ Konstantinides SV, Meyer G, Becattini C, et al. 2019 ESC Guidelines for the diagnosis and management of acute pulmonary embolism developed in collaboration with the European respiratory society (ERS). Eur Heart J 2020; 41(4): 543-603.

${ }^{[14]}$ D-Dimer, Quantitative - Clinical Education Center. Available at: http://education.questdiagnostics.com/faq/FAQ149. Accessed January 6, 2021.

${ }^{[15]}$ Righini M, Goehring C, Bounameaux H, Perrier A. Effects of age on the performance of. common diagnostic tests for pulmonary embolism. Am J Med 2000; 109(5): 357-361.

${ }^{[16]}$ Tita-Nwa F, Bos A, Adjei A, Ershler WB, Longo DL, Ferrucci L. Correlates of D-dimer in older persons. Aging Clin Exp Res 2010; 22(1): 20-23.

${ }^{[17]}$ Righini M, Van Es J, Den Exter PL, et al. Age-adjusted D-dimer cutoff levels to rule out pulmonary embolism: The ADJUST-PE study. JAMA - J Am Med Assoc 2014; 311(11):1117-24.

${ }^{[18]}$ Ge Y, Liu CH, Wang N, et al. Elevated Plasma D-Dimer in Adult Community-Acquired Pneumonia Patients is Associated with an Increased Inflammatory Reaction and Lower Survival. Clin Lab 2019; 65(1): 10.7754/Clin.Lab. 2018. 180720.

${ }^{[19]}$ Cerda-Mancillas MC, Santiago-Germán D, Andrade-Bravo B, et al. D-dimer as A Biomarker of Severity and Adverse Outcomes in Patients with Community Acquired Pneumonia. Arch Med Res 2020; 51(5): 429-435.

${ }^{[20]}$ Bunce PE, High SM, Nadjafi M, Stanley K, Liles WC, Christian MD. Pandemic H1N1 influenza infection and vascular thrombosis. Clin Infect Dis 2011; 52(2): 14-17.

${ }^{[21]}$ Poissy J, Goutay J, Caplan M, et al. Pulmonary Embolism in COVID-19 Patients: Awareness of an Increased Prevalence. Circulation 2020; 142(2): 184-186.
${ }^{[22]}$ Cook DJ, Crowther MA. Thromboprophylaxis in the intensive care unit: Focus on medical-surgical patients. Crit Care Med 2010; 38(2 Suppl.): S76-S82.

${ }^{[23]}$ Klok FA, Kruip MJHA, van der Meer NJM, et al. Incidence of thrombotic complications in critically ill ICU patients with COVID-19. Thromb Res 2020;191:145-147.

${ }^{[24]}$ Song WC, FitzGerald GA. COVID-19, microangiopathy, hemostatic activation, and complement. J Clin Invest 2020; 130 (8): 3950-3953.

${ }^{[25]}$ Yeh CH, de Wit K, Levy JH, et al. Hypercoagulability and coronavirus disease 2019-associated hypoxemic respiratory failure: Mechanisms and emerging management paradigms. J Trauma Acute Care Surg 2020; 89(6): e177-e181.

${ }^{[26]}$ Iba T, Levy JH, Levi M, Connors JM, Thachil J. Coagulopathy of Coronavirus Disease 2019. Crit Care Med 2020; 48(9): 1358-1364.

${ }^{[27]}$ Yonas E, Alwi I, Pranata R, et al. Elevated interleukin levels are associated with higher severity and mortality in COVID 19 - A systematic review, meta-analysis, and meta-regression. Diabetes Metab Syndr 2020; 14(6): 2219-2230.

${ }^{[28]}$ Bompard F, Monnier H, Saab I, et al. Pulmonary embolism in patients with Covid-19 pneumonia. Eur Respir J 2020; 56(1): 2001365.

${ }^{[29]}$ Zhou F, Yu T, Du R, et al. Clinical course and risk factors for mortality of adult inpatients with COVID-19 in Wuhan, China: a retrospective cohort study. Lancet 2020; 395(10229): 1054-1062.

${ }^{[30]} \mathrm{Li}$ J, Liu Z, Wu G, et al. D-Dimer as a Prognostic Indicator in Critically Ill Patients Hospitalized With COVID-19 in Leishenshan Hospital, Wuhan, China. Front Pharmacol 2020; 11: 600592.

${ }^{[31]}$ Van Dam LF, Kroft LJM, van der Wal LI, et al. Clinical and computed tomography characteristics of COVID-19 associated acute pulmonary embolism: A different phenotype of thrombotic disease? Thromb Res 2020; 193: 86-89.

${ }^{[32]}$ Espallargas I, Rodríguez Sevilla JJ, Rodríguez Chiaradía DA, et al. CT imaging of pulmonary embolism in patients with COVID-19 pneumonia: a.retrospective analysis. Eur Radiol 2020; 1-8.

${ }^{[33]}$ Fauvel C, Weizman O, Trimaille A, et al. Pulmonary embolism in COVID-19 patients : a French multicentre cohort study. Eur Heart J 2020;41(32):3058-3068.

${ }^{[34]}$ Bikdeli B, Madhavan M V., Jimenez D,.et al. COVID-19 and Thrombotic or Thromboembolic Disease: Implications for Prevention, Antithrombotic Therapy, and Follow-Up: JACC Stateof-the-Art Review. J Am Coll Cardiol. 2020; 75(23): 2950-73. 